\title{
PENGARUH EMPLOYEE ENGAGEMENT TERHADAP JOB PERFORMANCE MELALUI CREATIVITY SEBAGAI VARIABEL MEDIASI
}

\author{
Agil Rasul Baharsyah \\ Universitas Negeri Surabaya \\ agil.17080574065@mhs.unesa.ac.id \\ Dwiarko Nugrohoseno \\ Universitas Negeri Surabaya \\ dwiarkonugrohoseno@unesa.ac.id
}

\begin{abstract}
The purpose of this paper is to explore the relationship between employee engagement and job performance and to test whether creativity mediates the relationship between engagement and job performance. Job performance is the result of contributions made by employees to the company. Previous research found that employee engagement and creativity were the strongest predictors of job performance. Therefore, the research here wants to test whether creativity is a mediator variable of the two constructs. The sample in this study amounted to 96 banking employees in Sumenep Regency using the snowball sampling method in data collection. The results of the model equation test show that employee engagement has no significant effect on job performance. Employee engagement has a significant effect on creativity. Creativity has a significant effect on job performance. In addition, creativity as a mediator variable has a significant effect on the relationship between employee engagement and job performance. Employee engagement is not directly related to job performance but is mediated by creativity. The managerial implication of the results of this study is that banking companies can review the factors that can hinder or reduce their employee engagement to maintain the employee's job performance.
\end{abstract}

Keywords: creativity; employee engagement; job performance.

\section{PENDAHULUAN}

Seiring perkembangan jaman revolusi industri, semakin menuntut perubahan pada berbagai sektor bidang industri di Indonesia. Tidak terkecuali pada sektor industri perbankan. Perkembangan ini ditandai dengan munculnya teknologi yang dapat membantu meningkatkan proses pelayanan antara perusahaan dengan nasabahnya. Terdapat banyak sekali inovasi yang dilakukan perbankan diseluruh Indonesia untuk meningkatkan layanan terhadap nasabahnya. Hal ini bertujuan untuk menghadapi persaingan di era digital yang semakin pesat dengan seiringnya jaman (Citradi, 2021).

Industri perbankan harus bisa beradaptasi dengan kondisi saat ini, sehingga setiap karyawan dituntut untuk dapat menggali segala potensi yang dimiliki, secara harfiah keberhasilan dalam skala kecil (individual) memiliki dampak penting atas keberhasilan berskala besar (perusahaan) (Parlinda \& Wahyuddin, 2008). Di sisi lain merujuk pada Global Talent Competitiveness Index yang menjelaskan bahwa Indonesia peringkat 65 dari 132 negara untuk kategori kualitas tenaga kerja. Secara keseluruhan, target meningkatkan kualitas sumber daya manusia juga memerlukan pengelolaan yang terbaik (INSEAD, 2020).

Menurut Anitha (2014) penekanan dari job performance adalah hasil yang didapatkan dari proses bekerja sehari-hari dalam organisasi maupun instansi yang berupa bentuk kontribusi yang positif. Hal ini ditandai dari indikator yang dapat diamati adalah kecakapan, performa dalam mengerjakan tugas, kemampuan dalam melaksanakan projek, serta kesehatan fisik dan mental selama masa bekerja. Karyawan yang memiliki kinerja yang tinggi, kemungkinan hal tersebut membuktikan bahwasannya karyawan di perusahaan tersebut memiliki tingkat engagement yang tinggi juga pada perusahaannya. Employee engagement merupakan prediktor terkuat terhadap job performance (Markos \& M. Sridevi, 2010). 
Agil Rasul Baharsyah \& Dwiarko Nugrohoseno. Pengaruh Employee Engagement terhadap Job Performance melalui Creativity sebagai Variabel Mediasi

Menurut Perrin (2003) employee engagement adalah kemauan pekerja serta usahanya dalam mendukung visi misi perusahaan secara berkelanjutan. Dalam hal ini terdapat beberapa faktor yang terikat yaitu emosional dan rasional, di mana hal ini diperoleh oleh terdapatnya pengalaman pribadi sebelum ataupun ketika mereka bekerja. Macey \& Schneider (2008) menyajikan semua elemen yang dianalisis secara komprehensif dan relevan, di mana hal ini mendefinisikan engagement terkait: trait engagement (misalnya ciri kepribadian individu), work involvement (misalnya kepuasan, keterlibatan, pemberdayaan), dan organizational citizenship (misalnya perilaku peran ekstra, proaktif, perluasan peran).

Beberapa penelitian terdahulu menemukan hubungan positif employee engagement terhadap job performance (Anitha, 2014; Bakker \& Bal, 2010; Dajani, 2015). Namun, hasil penelitian lain mengungkapkan bahwa hubungan employee engagement berpengaruh tidak signifikan terhadap job performance pada karyawan salah satu perusahaan di Batam, hal ini bermakna bahwa ketika karyawan tersebut memiliki employee engagement yang tinggi hal tersebut tidak akan berdampak pada job performance mereka (Mahadika \& Hadi, 2018). Secara konsisten telah ditunjukkan dalam banyak penelitian di bidang ini bahwa employee engagement memiliki efek positif terhadap job performance. Selain itu, akademisi berpendapat bahwa diperlukan lebih banyak penelitian lagi mengenai variabel yang berpotensi memiliki pengaruh mediasi pada hubungan employee engagement terhadap job performance. Hal ini sejalan dengan seruan penelitian Eldor (2017) untuk mengidentifikasi faktor-faktor yang menghambat atau mendorong hubungan antara kedua variabel. Oleh karena itu, bukti awal menemukan hubungan antara employee engagement terhadap job performance bukan merupakan hubungan langsung, akan tetapi terdapat beberapa faktor yang memediasi hubungan antara dua konstruk tersebut (Karatepe \& Ngeche, 2012).

Studi terbaru dari Slatten \& Mehmetoglu (2011) dan Alfes et al. ( 2013) menemukan bahwa employee engagement dianggap sebagai anteseden kritis creativity dan inovasi karyawan di tempat kerja. Harter et al. (2003) menyatakan bahwa employee engagement adalah sebuah konstruk yang mendorong setiap individu karyawan terlibat pada pekerjaannya yang pada akhirnya memunculkan creativity karyawan dalam bekerja. Menurut Hughes et al. (2018) creativity sebagai sesuatu yang menyangkut proses kognitif dan perilaku yang diterapkan ketika mencoba menghasilkan ide-ide baru. Kapasitas tersebut dapat membantu menyelesaikan masalah sedangkan inovasi melibatkan penerapan atau pengubahan ide-ide baru menjadi praktik (implementasi). Dalam konteks organisasi, creativity mengacu pada generasi ide baru tentang produk, proses, atau prosedur yang mungkin berguna bagi organisasi (Shalley \& Gilson, 2004). Creativity dapat dipengaruhi oleh faktor kontekstual, seperti pekerjaan yang menantang, dorongan organisasi, kebebasan, sumber daya yang cukup, dan tekanan beban kerja (Ghosh, 2015). Namun, pada penelitian Soori \& Ferasat (2016) menemukan bahwa hubungan creativity terhadap job performance adalah hubungan yang sangat lemah. Di sisi lain, creativity juga telah terbukti mempunyai hubungan positif yang signifikan terhadap job performance dalam studi empiris (Eschleman et al., 2014).

Dari hasil observasi yang telah dilakukan pada industri perbankan di Kabupaten Sumenep, menemukan adanya perubahan jam kerja yang dilakukan perusahaan terhadap karyawannya akibat dampak terjadinya pandemi covid-19 hingga saat ini. Di mana para karyawan yang bekerja diperlakukan sistem shift kerja, sehingga karyawan yang bekerja tidak semuanya masuk pada jam yang sama akan tetapi bergantian. Karena perubahan jam kerja ini, karyawan merasakan ada hal yang berbeda pada lingkungan kerja mereka. Sehingga secara tidak langsung ini akan menimbulkan rasa jenuh pada karyawan ketika mereka sedang bekerja. Pandemi ini tidak hanya merubah jam kerja karyawan akan tetapi target bulanan yang telah ditentukan perusahaan juga mengalami pengurangan, dengan harapan karyawan masih dapat berkontribusi aktif meskipun dalam kondisi pandemi saat ini. Selain itu, dari hasil wawancara dengan ibu $X$ yang merupakan salah satu karyawan industri perbankan mengungkapkan bahwa perusahaannya memberi kebebasan bagi karyawan dalam bekerja namun tetap mengikuti SOP perusahaan yang berlaku. Sampel pada penelitian ini menggunakan karyawan industri perbankan yang bekerja di Kabupaten Sumenep. 
Berdasarkan research gap dan fenomena di atas, tujuan penelitian ini adalah untuk menganalisis serta menguji efek mediasi variabel creativity dalam pengaruh employee engagement terhadap job performance.

\section{KAJIAN PUSTAKA DAN PENGEMBANGAN HIPOTESIS}

\section{Employee Engagement}

Employee engagement secara harfiah diartikan sebagai usaha atau kemampuan seorang pekerja dalam mengerjakan tugas sebaik mungkin secara individu maupun kelompok, di mana mereka harus mengelola aspek personal seperti energi, emosional, serta kemampuan kognitif yang bersifat positif sehingga karyawan yang sangat engaged menunjukkan hasrat untuk menyelesaikan tugas terkait pekerjaan sebaik mungkin, di mana hal ini menunjukkan tingkat loyalitas kepada perusahaaan atau organisasi terkait (Truss et al., 2013). Sedangkan menurut Kahn (1990) mengkonseptualisasikan definisi dari employee engagement adalah sebagai sebuah pemanfaatan pekerja perorangan dalam organisasi untuk melaksanakan kewajiban, baik dalam keterlibatan pada pekerjaanya, serta menunjukkan perasaan secara emosional dan tingkah laku secara fisik selama perannya untuk menghasilkan kinerja. Menurut Thomas (2007) employee engagement adalah keterkaitan antara tempat kerja secara emosional terhadap pekerjanya, di mana ciri engagement ini sendiri ketika seorang individu secara sadar memiliki semangat dan tanggung jawab pada pekerjaannya. Sehingga dapat diartikan bahwa employee engagement merupakan persepsi, perilaku, serta perasaan yang dimiliki oleh seorang individu serta mengembangkan kondisi lingkungan kerja mereka.

\section{Job Performance}

Deadrick \& Gardner (1999) mendefinisikan job performance sebagai hasil kerja yang dicapai untuk setiap fungsi pekerjaan selama periode waktu tertentu. Job performance didefinisikan sebagai hasil yang berhubungan dengan pekerjaan yang mengacu pada tujuan untuk mencapai tujuan organisasi yang diukur dengan evaluasi kinerja pada tugas-tugas yang berubungan dengan pekerjaan (Sharma $e t$ al., 2009). Menurut Murphy \& Kroeker (1989) job performance sebagai fungsi kinerja individu pada tugas-tugas tertentu yang membantu organisasi dalam mencapai tujuannya. Menurut Viswesvaran \& Ones (2000) job performance mengacu pada tindakan, perilaku, dan hasil yang dapat diperhitungkan dan dihasilkan karyawan yang terkait dengan kontribusi karyawan pada tujuan organisasi. El-Sabaa (2001) menjelaskan bahwa job performance berkaitan dengan kemauan dan keterbukaan untuk mencoba dan mencapai aspek-aspek baru di pekerjaan, yang akan membawa peningkatan produktivitas individu. Sehingga dapat diartikan bahwa job performance merupakan sebuah hasil yang telah dicapai oleh seorang individu dalam mengerjakan tugas pekerjaan mereka sehingga akan berdampak pada tujuan organisasi itu sendiri.

\section{Creativity}

Menurut Hughes et al. (2018) creativity sebagai sesuatu yang menyangkut proses kognitif dan perilaku yang ketika diterapkan mencoba menghasilkan ide-ide baru. Kapasitas tersebut dapat membantu menyelesaikan masalah sedangkan inovasi melibatkan penerapan atau pengubahan ide-ide baru menjadi praktik (implementasi). Menurut Sanny et al. (2013) creativity adalah kemampuan yang dimiliki seseorang untuk menemukan ide atau inovasi baru mengenai suatu hal baru baik berupa gagasan, benda ataupun karya yang memiliki dampak positif pada pekerjaannya. Menurut Shin et al. (2012) creativity sebagai gagasan baru yang berguna bagi organisasi terkait hal-hal yang membantu seseorang dalam bekerja. Mathisen et al. (2012) memandang creativity sebagai perilaku yang menghasilkan ide-ide yang berguna untuk pengembangan usaha dan menyatakan bahwa pemimpin organisasi memainkan peran penting dalam mempromosikan creativity dengan mendorong keterbukaan dan menerapkan pemikiran imajinatif dan lebih modern untuk pemecahan masalah.

\section{Hubungan antar Variabel}

Employee engagement menyebabkan job performance karyawan meningkat tinggi dengan menunjukkan sikap positif dan memotivasi dirinya sendiri serta bertanggung jawab pada pekerjaan mereka (Parker \& Griffin, 2011). Stairs \& Galpin (2009) menemukan ketika employee engagement 
Agil Rasul Baharsyah \& Dwiarko Nugrohoseno. Pengaruh Employee Engagement terhadap Job Performance melalui Creativity sebagai Variabel Mediasi

meningkat tinggi hal itu berdampak positif terhadap job performance. Dalam hal ini, studi empiris sebelumnya telah mengindikasikan keterkaitan antara employee engagement terhadap job performance yang memiliki pengaruh positif antara satu sama lain. Misalnya Bakker \& Bal (2010) meneliti hubungan antara employee engagement mingguan dan job performance di antara 54 guru di Belanda menggunakan analisis multi-level. Mereka menemukan bahwa employee engagement mingguan dan job performance mingguan berhubungan positif. Anitha (2014) juga memelajari hal yang sama yaitu pengaruh employee engagement terhadap job performance, di mana keduanya saling berpengaruh secara positif satu sama lain. Namun, pada penelitian Mahadika \& Hadi (2018) mengungkapkan hal penting yang tertulis dalam karya observasinya yang menyatakan bahwa employee engagement tidak memiliki hubungan dengan job performance, dalam artian keduanya berpengaruh tidak signifikan pada karyawan salah satu perusahaan di Batam. Dengan demikian, sebagian besar temuan penelitian sebelumnya telah menunjukkan keterkaitan di antara dua aspek yaitu employee engagement dan job performance secara positif signifikan, di mana pekerja yang terlibat diharapkan menunjukkan performance terbaik dibandingkan dengan karyawan yang jauh dari kategori engaged (Demerouti \& Cropanzano, 2010).

H1 : Employee engagement berpengaruh signifikan terhadap job performance.

Alfes et al. (2013) menunjukkan bahwa karyawan yang terlibat lebih baik dalam mengembangkan solusi kreatif, berpikir inovatif dan menggunakan penalaran yang fleksibel dalam situasi organisasi yang menantang. Dukungan lebih lanjut untuk hubungan antara employee engagement dan creativity oleh Slatten \& Mehmetoglu (2011) yang melakukan penelitian di industri perhotelan, menemukan bahwa employee engagement terkait erat dengan perilaku inovatif karyawan. Manajer harus mengukur employee engagement mereka karena hal itu adalah pendorong utama perilaku inovatif. Karyawan yang engaged akan lebih produktif dan mereka mencoba menerapkan metode inovatif untuk melebihi hasil yang diminta (Ahmetoglu et al., 2015). Ini menyiratkan bahwa karyawan yang terlibat menikmati pekerjaan dan tugas mereka, yang membuat mereka berpikir kreatif dan bergerak maju bahkan dalam situasi yang tidak pasti (Ismail et al., 2019).

\section{$\mathrm{H} 2$ : Employee engagement berpengaruh signifikan terhadap creativity.}

Karyawan yang kreatif mampu menemukan solusi baru untuk masalah dan tantangan pekerjaan yang sedang mereka hadapi dan memungkinkan mereka bekerja lebih efektif dalam memenuhi tugas serta tanggung jawab pekerjaan yang pada akhirnya meningkatkan kinerja mereka di tempat kerja. Namun demikian, penting untuk disoroti bahwa hubungan antara creativity dan job performance bukanlah hubungan langsung, akan tetapi bergantung pada berbagai variabel pribadi dan organisasi yang dapat mendukung atau membatasi creativity di tempat kerja (Amabile et al., 1996). Beberapa studi empiris menunjukkan hubungan positif antara creativity dan job performance, misalnya, Suh \& Shin (2005) melakukan studi untuk mengeksplorasi hubungan antara creativity dan job performance serta korelasinya di organisasi nirlaba, ditemukan hubungan yang positif signifikan di antara dua konstruks tersebut. Organisasi dapat mengungguli pesaing mereka dengan menyediakan lingkungan kreatif bagi karyawannya dan peluang untuk berpikir dan bertindak secara berbeda. Selain itu, Taboli \& Mostafa (2016) menguji pengaruh creativity pada job performance dengan peran mediasi kepemimpinan etis staff kantor pusat di sebuah universitas ilmu kedokteran. Hasilnya menemukan bahwa creativity memiliki pengaruh yang positif signifikan terhadap job performance, serta menemukan bahwa klarifikasi tugas dan hal-hal terkait staff mendorong karyawan untuk berpartisipasi dalam pengambilan keputusan dapat meningkatkan produktivitas dan job performance mereka di tempat kerja. Namun pada penelitian Soori \& Ferasat (2016) menemukan hubungan yang sangat lemah antara employee engagement terhadap job performance, penelitian ini dilakukan pada 590 pegawai Kota Khorrahmabad.

H3 : Creativity berpengaruh signifikan terhadap job performance.

Berdasarkan literatur di atas, model ini secara khusus menghipotesiskan bahwa employee engagement dalam sebuah pekerjaan akan menghasilkan creativity yang dapat meningkat di tempat kerja, di mana 
pada muara akhir dampak yang terlihat jelas adalah keterkaitan positif terhadap job performance di tempat mereka bekerja. Penelitian yang senada juga dikemukakan oleh Ismail et al. (2019) di mana mengemukakan bahwa creativity telah memediasi hubungan antara employee engagement terhadap job performance pada 186 responden yang bekerja di Lebanon. Isaksen \& Ekvall (2010) mencatat bahwa ketika karyawan merasakan engaged yang lebih dalam dan merasakan suasana yang kondusif dalam bekerja, mereka akan menciptakan creativity dan menghasilkan manfaat bagi pekerjaan mereka, termasuk job performance. Ketika seseorang menjadi kreatif, mereka akan bekerja lebih cerdas saat mereka mulai mengembangkan cara-cara inovatif dalam memecahkan masalah pekerjaan sehari-hari yang pada gilirannya berdampak positif terhadap job performance mereka secara keseluruhan (Amabile \& Kramer, 2007). Di sisi lain, ketika karyawan menemukan pekerjaannya tidak menarik, mereka mungkin menjadi kurang termotivasi dan kurang engaged dalam pekerjaan mereka, yang dapat mengurangi motivasi mereka untuk berpikir kreatif dalam menyelesaikan masalah pekerjaan dan oleh karena itu mengarah pada masalah kinerja. Oleh karena itu, temuan ini menegaskan bahwa employee engagement berhubungan tidak langsung terhadap job performance dan dimediasi oleh creativity. Berikut asumsi hipotesis yang diajukan peneliti:

H4 : Creativity memediasi hubungan antara employee engagement dan job performance.

Hubungan antar variabel ini digambarkan dalam bentuk kerangka berfikir pada gambar 1.

\section{METODE PENELITIAN}

Penelitian ini menggunakan metode kuantitatif dengan penentuan sampel dipilih menggunakan snowball sampling. Proses pengambilan sampel awal dilakukan hanya pada beberapa responden yang kemudian diteruskan kepada rekan-rekan mereka, sehingga jumlah sampel menjadi lebih banyak. Jumlah sampel yang terkumpul sebanyak 96 orang yang merupakan karyawan dari 8 perusahaan perbankan di Kabupaten Sumenep yang berpartisipasi dalam survey ini menggunakan Google Form. Media yang digunakan untuk mengambil data penelitian yaitu wawancara dan kuesioner. Structural equation modelling (SEM) merupakan analisis statistik pada penelitian ini, dengan memanfaatkan aplikasi SmartPLS versi 3.0.

Skala likert 1-5 digunakan dalam penelitian ini untuk menilai 28 item pernyataan dari 3 variabel yang diteliti. Variabel employee engagement menggunakan 9 item pernyataan yang dijelaskan melalui pendapat Schaufeli et al. (2006) bahwa terdapat 3 indikator yaitu vigor, dedication, dan absorption. Variabel job performance di sini menggunakan 6 item pernyataan yang dikemukakan oleh Singh et al. (1996) yang terdiri dari 6 indikator yaitu kuantitas dalam bekerja, kemampuan mencapai tujuan, potensi kinerja, hubungan dengan pelanggan, kemampuan manajemen, dan pengetahuan produk. Variabel creativity di sini menggunakan 13 item pernyataan dari Zhou \& George (2001) yang terdiri dari 3 indikator yaitu banyak muncul ide-ide baru, mampu menciptakan solusi, dan kemauan bekerja keras.

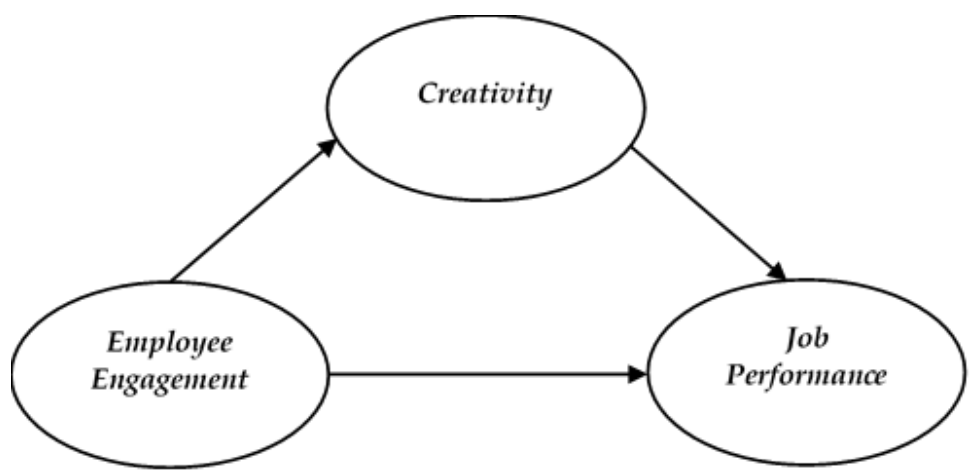

Gambar 1. KERANGKA KONSEPTUAL 
Agil Rasul Baharsyah \& Dwiarko Nugrohoseno. Pengaruh Employee Engagement terhadap Job Performance melalui Creativity sebagai Variabel Mediasi

\section{HASIL DAN PEMBAHASAN}

\section{Karakteristik Responden}

Data responden yang berhasil terkumpul berjumlah 96 karyawan yang bekerja di industri perbankan di Kabupaten Sumenep. Karakterisitik responden berdasarkan usia adalah 20-25 tahun sebanyak 36 orang (37,5\%), 26-30 tahun yaitu 49 orang (51\%), 31-35 tahun yaitu 9 orang (9,4\%), 36-40 tahun yaitu 1 orang $(1,05 \%)$, dan $>40$ tahun yaitu 1 orang $(1,05 \%)$. Pada penelitian ini responden didominasi oleh perempuan yang berjumlah 60 orang $(62,5 \%)$ dan laki-laki 36 orang $(37,5 \%)$. Pendidikan yang dimiliki responden pada penelitian ini memiliki perbedaan, responden yang berpendidikan SLTA sebanyak 16 orang (16,7\%), D3 sebanyak 12 orang (12,5\%), S1 sebanyak 68 orang $(70,8 \%)$. Status hubungan pada responden terbagi menjadi 2 yaitu menikah dan belum menikah, responden yang memiliki status menikah berjumlah 27 orang $(28,1 \%)$ sedangkan status belum menikah pada responden berjumlah 69 orang $(71,9 \%)$. Karakteristik responden berdasarkan gaji, karyawan yang memiliki gaji Rp1.000.000- Rp2.900.000 berjumlah 39 orang (40,6\%), Rp3.000.000Rp4.900.000 sebanyak 54 orang (56,3\%), dan Rp5.000.000- Rp7.900.000 sebanyak 3 orang (3,1\%). Karakteristik respoden berdasarkan masa kerja, responden dengan masa kerja $<1$ tahun tergolong sedikit hanya berjumlah 2 orang $(2,1 \%)$, sedangkan pada kategori 1-3 tahun memiliki jumlah yang paling banyak yaitu 69 orang (71,9\%), 4-6 tahun sebanyak 20 orang (20,8\%), di atas 7 tahun sebanyak 5 orang $(5,2 \%)$. Responden di sini memiliki perbedaan dalam hal bidang pekerjaannya, bagian Teller pada responden penelitian ini berjumlah 22 orang (22,9\%), Customer Service berjumlah 19 orang (19,8\%), Community Officer dan Marketing berjumlah 12 orang (25\%), Sales Officer sebanyak 7 orang (7,4\%), Auditur Keuangan, Auditur Emas, Asisten Manajer, AOP, Support, dan Accounting memiliki jumlah yang sama yaitu 1 orang (6\%), Account Officer dan Admin Kredit berjumlah 4 orang $(8,4 \%)$, Admin sebanyak 6 orang $(6,3 \%)$, serta Admin IT dan Analisis Kredit berjumlah 2 orang $(4,2 \%)$. Karakteristik responden berdasarkan perusahaan, responden yang bekerja di Bank BCA sebanyak 10 orang (10,5\%), Bank BNI dan Bank Jatim berjumlah 11 orang (11,5\%), Bank BTN berjumlah 12 orang (12,5\%), serta Bank BRI, Bank BPRS, Bank BTPN, dan Bank Mandiri memiliki jumlah yang sama yaitu 13 orang $(13,5 \%)$.

\section{Analisis Deskriptif}

Hasil analisis data deskriptif diolah menggunakan pengategorian data Widhiarso (2010). Responden yang memiliki persepsi tinggi terhadap employee engagement sebanyak 80 orang $(83,3 \%)$ dan persepsi sedang sebanyak 16 orang $(16,7 \%)$. Persepsi karyawan industri perbankan terhadap job performance yang memiliki kategori tinggi sebanyak 82 orang $(85,4 \%)$ dan kategori sedang sebanyak 14 orang $(14,6 \%)$. Selain itu juga, pada creativity yang memiliki kategori tinggi sebanyak 71 orang (74\%) dan kategori sedang sebanyak 25 orang (26\%).

\section{Convergen Validity}

Variabel penelitian ini dapat dikatakan memiliki nilai refleksif tinggi jika memiliki nilai loading di atas 0,70. Akan tetapi jika pengolahan data penelitian dilakukan pertama kali dan memeroleh nilai loading di atas 0,50 sudah dikatakan cukup memenuhi (Ghozali, 2014). Hasil pengujian diketahui model konstruk penelitian ini dikatakan valid dengan nilai loading di atas 0,60.

\section{Composite Reliability and Cronbach's Alpha}

Tabel 1.

COMPOSITE RELIABILITY DAN CRONBACH'S ALPHA

\begin{tabular}{ccc}
\hline Variabel & Composite Reliability & Cronbach's Alpha \\
\hline Employee Engagment & 0,910 & 0,852 \\
Job Performance & 0,914 & 0,858 \\
Creativity & 0,883 & 0,840 \\
\hline
\end{tabular}

Sumber: output SmartPLS, data diolah 
Berdasarkan hasil yang didapatkan dari pengujian di tabel 1, composite reliability, dan cronbach's alpha dapat dikategorikan baik dan kuat, karena hasil uji penelitian nilai composite reliability $>0,60$ serta nilai cronbach's alpha $>0,70$.

\section{R-Square}

Hasil olah data penelitian ini menghasilkan nilai $R$-square di tabel 2.

Tabel 2.

\section{R-SQUARE}

\begin{tabular}{cc}
\hline Variabel & R-Square \\
\hline Employee Engagement & \\
Job Performance & 0,401 \\
Creativity & 0,463 \\
\hline
\end{tabular}

Sumber: output SmartPLS, data diolah

Pada tabel 2 menjelaskan seberapa besar pengaruh employee engagement pada job performance yang menghasilkan nilai sebesar 0,401 dari hasil analisis $R$-Square. Di mana nilai ini juga bisa di intrepretasikan bahwa variabel konstruk job performance bisa dijelaskan oleh variabel job performance sebanyak 40,1\% sedangkan 59,9\% dapat dipengaruhi oleh variabel selain employee engagement, yaitu variabel yang tidak digunakan pada penelitian yang dilakukan. Selain itu, pada tabel tersebut juga menunjukkan model pengaruh employee engagement terhadap creativity yang menghasilkan nilai $R$-Square yaitu $46,3 \%$ dan hal tersebut menggambarkan variabel konstruk creativity secara nyata dapat dijelaskan oleh variabel employee engagement sebesar 46,3\% dan 53,7\% dikembangkan oleh variabel selain employee engagement, yaitu variabel yang tidak ada pada penelitian ini.

Uji Kausalitas

Inner model digunakan untuk mengetahui adanya pengaruh signifikan pada variabel yang diteliti. Pengaruh langsung dan tidak langsung variabel yang diperoleh dari path coefficients dan indirect effects pada tabel 3 .

Tabel 3.

DIRECT \& INDIRECT EFFECT VARIABLE

\begin{tabular}{lcccc}
\hline \multicolumn{1}{c}{ Variabel } & $\begin{array}{c}\text { Original } \\
\text { Sample }\end{array}$ & T-statistics & Keterangan & P-Values \\
\hline Employee Engagement $\rightarrow$ Job Performance & 0,129 & 0,854 & $\leq 1,96$ & 0,394 \\
Employee Engagement $\rightarrow$ Creativity & 0,680 & 12,252 & $\geq 1,96$ & 0,000 \\
Creativity $\rightarrow$ Job Performance & 0,538 & 4,974 & $\geq 1,96$ & 0,000 \\
Employee Engagement $\rightarrow$ Creativity $\rightarrow$ Job & 0,366 & 4,239 & $\geq 1,96$ & 0,000 \\
Performance & & & & \\
\hline
\end{tabular}

Sumber: Hasil penelitian, data diolah

Berdasarkan tabel 3, nilai $t$-statistics employee engagement terhadap job performance sebesar 0,854 $\leq$ 1,96. Hal ini menunjukkan tidak ada pengaruh signifikan antara kedua konstruk variabel. Sedangkan, nilai $t$-statistics employee engagement terhadap creativity sebesar $12,252 \geq 1,96$. Hal ini menjelaskan bahwa terdapat pengaruh yang signifikan antara kedua konstruk variabel. Hasil $t$-statistics creativity terhadap job performance sebesar $4,974 \geq 1,96$. Artinya terdapat pengaruh yang signifikan terhadap kedua konstruk variabel tersebut. Selain itu, creativity terbukti memediasi secara signifikan terhadap hubungan antara employee engagement dan job performance dengan nilai $t$-statistics $4,239 \geq 1,96$. 
Agil Rasul Baharsyah \& Dwiarko Nugrohoseno. Pengaruh Employee Engagement terhadap Job Performance melalui Creativity sebagai Variabel Mediasi

\section{Pengaruh Employee Engagement terhadap Job Performance Karyawan Industri Perbankan di Kabupaten Sumenep}

Berdasarkan hasil penelitian yang telah dilakukan, employee engagement tidak berpengaruh signifikan terhadap job performance karyawan industri perbankan di Kabupaten Sumenep. Sehingga H1 pada penelitian ini ditolak. Hasil ini menjelaskan walaupun employee engagement relatif tinggi akan tetapi tidak akan selalu dapat meningkatkan job performance mereka di perusahaan. Secara keseluruhan penelitian ini sependapat dengan hasil penelitian Munparidi \& Sayuti (2020) bahwa employee engagement memiliki pengaruh tidak signifikan terhadap job performance karyawan biro perjalanan di kota Palembang. Namun, pada penelitian Dajani (2015) menyatakan hal yang berbeda, di mana terdapatnya pengaruh positif dan signifikan hubungan employee engagement terhadap job performance karyawan yang berkerja di perbankan swasta maupun pemerintah di Kairo, Mesir. Ketika karyawan merasa nyaman dengan lingkungan pekerjaannya mereka akan lebih mudah engaged dengan pekerjaanya.

Hasil tidak signifikan ini mungkin dikarenakan terdapat perubahan kebijakan yang memengaruhi lingkungan internal perusahaan selama pandemi covid-19 ini berlangsung, seperti adanya perubahan jam kerja masuk karyawan dan perubahan target bulanan yang telah ditetapkan perusahaan pada karyawannya. Perubahan jam masuk kerja karyawan yang dilakukan perusahaan membuat karyawan jadi lebih mudah jenuh pada pekerjaannya, karena karyawan merasakan ada sesuatu hal berbeda ketika mereka bekerja sebelum dan selama pandemi ini terjadi. Sehingga hubungan antara employee engagement terhadap job performance ini kemungkinan dipengaruhi oleh variabel lain.

Hasil analisis deskriptif responden pada variabel employee engagement tergolong dalam kategori tinggi, sehingga dapat diartikan bahwa karyawan industri perbankan di Kabupaten Sumenep memiliki persepsi yang tinggi terhadap variabel ini. Wawancara tidak terstruktur dilakukan dengan salah satu karyawan industri perbankan di Kabupaten Sumenep yang menyatakan bahwa karyawan merasa bahagia dan semangat dengan pekerjaannya karena karyawan merasa dapat membantu menyejahterakan nasabahnya, meningkatkan usaha nasabahnya, membantu mimpi nasabahnya, dan bisa lebih dekat dengan masyarakat. Selain itu, karyawan yang terlibat pada pekerjaan hal itu menunjukkan sikap profesionalitas dalam bekerja dan hal tersebut akan mengembangkan karir karyawan tersebut kedepannya. Selanjutnya, hasil wawancara dengan karyawan marketing mengungkapkan bahwa target yang diberikan perusahaan berbeda-beda setiap bulannya. Target bulanan pun terbagi menjadi dua yaitu target team (uang) dan target individu (nasabah). Ketika seorang karyawan tidak mampu mencapai target perusahaan selama tiga bulan berturut-turut, maka pemimpin perusahaan akan memberi peringatan dan memberi training terkait kendala-kendala yang dihadapi karyawan di lapangan. Namun, jika tidak ada perubahan maka pemutusan hubungan kerja adalah solusi yang dilakukan perusahaan.

\section{Pengaruh Employee Engagement terhadap Creativity Karyawan Industri Perbankan di Kabupaten Sumenep}

Hasil pengujian menemukan bahwa employee engagement berpengaruh signifikan terhadap creativity karyawan industri perbankan di Kabupaten Sumenep. Sehingga $\mathrm{H} 2$ dalam penelitian ini diterima dan hal tersebut dapat diartikan bahwa Ketika karyawan merasakan engagement yang tinggi pada pekerjaannya maka creativity yang dimilikinya juga akan meningkat tinggi. Selain itu, Ketika karyawan bisa mendedikasikan dirinya pada pekerjaan mereka baik secara tindakan, kognitif ataupun juga dari sisi emosional mereka untuk memberikan energi yang besar terhadap pekerjaan, hal tersebut akan mengarah pada perilaku kreatif (Tong et al., 2019). Selanjutnya hasil penelitian juga diperkuat dengan adanya pengaruh positif secara signifikan terhadap perilaku yang inovatif dan employee engagement pada pekerjaannya terhadap creativity (Kong \& Li, 2018). Sehingga dapat dijelaskan bahwa karyawan yang merasakan engaged pada pekerjaan hal itu akan memunculkan sisi creativity yang dimiliki mereka sehingga akan membantu mereka dalam bekerja dan berdampak positif terhadap kinerjanya.

Hasil analisis deskriptif menunjukkan bahwa nilai kategori untuk variabel creativity cukup tinggi dan dapat diartikan bahwa karyawan industri perbankan di Kabupaten Sumenep memiliki persepsi yang 
tinggi terhadap variabel ini. Hal ini juga didukung dengan hasil wawancara tidak terstruktur pada salah satu karyawan yang bekerja di industri perbankan di Kabupaten Sumenep yang menyatakan bahwa ketika karyawan sudah merasa nyaman dengan pekerjaannya, mereka akan dengan mudah untuk mengeksplore pekerjaannya dan terkadang akan memunculkan ide-ide dan inovasi baru yang dapat membantunya dalam bekerja dan hal itu akan berdampak positif juga terhadap perusahaan. Salah satu penerapannya pada bidang marketing, di saat pandemi seperti sekarang karyawan menggunakan media sosial salah satunya TikTok sebagai media promosi untuk menarik perhatian calon nasabahnya maupun memberikan informasi pada nasabah tetapnya.

\section{Pengaruh Creativity terhadap Job Performance Karyawan Industri Perbankan di Kabupaten Sumenep}

Hasil pengujian hipotesis menemukan bahwa creativity berpengaruh signifikan terhadap job performance karyawan industri perbankan di Kabupaten Sumenep, sehingga $\mathrm{H} 3$ pada penelitian ini dapat diterima secara keseluruhan. Hal tersebut menjelaskan bahwa ketika creativity karyawan industri perbankan di Kabupaten Sumenep meningkat ketika mereka bekerja maka job performance mereka juga akan meningkat. Selain itu, creativity muncul karena tantangan pekerjaan yang dihadapi membuat karyawan berpikir kreatif sehingga memunculkan ide-ide yang dapat membantu pekerjaannya. Creativity yang dimiliki karyawan memiliki dampak terhadap kinerjanya, kesuksesan, serta keberhasilan di masa depan terkait kemajuan perusahaan (Anderson et al., 2014). Penelitian Eschleman et al. (2014) menjadi hal penguat, di mana penelitian ini mengambil dua sampel responden. Studi pertama menggunakan sampel karyawan yang memberikan hasil terkait job performance melalui penilaiannya dilakukan oleh dirinya sendiri, sedangkan studi kedua mengggunakan sampel karyawan yang hasil job performance yang dinilai oleh orang lain (rekan kerja). Pada penelitian ini menyatakan bahwa creativity juga telah terbukti adanya keterkaitan yang positif dan menunjukkan hal yang signifikan pada job performance. Hasil penelitian ini juga sependapat dengan temuan hubungan positif employee engagement terhadap job performance yang merupakan hasil penelitian (Suh \& Shin, 2005; Taboli \& Mostafa, 2016).

Hasil analisis deskriptif responden pada variabel job performance tergolong dalam kategori tinggi, sehingga dapat dijelaskan bahwa responden memiliki persepsi yang tinggi terhadap variabel ini. Dalam hal ini, hasil wawancara tidak terstruktur yang dilakukan pada salah satu karyawan industri perbankan di Kabupaten Sumenep mengungkapkan bahwa mereka selalu menggunakan creativity yang mereka miliki dalam bekerja misalnya menggunakan metode pendekatan yang berbeda-beda kepada setiap nasabahnya, salah satunya pendekatan komunikasi yang dilakukan sesuai dengan kepribadian nasabahnya. Karena jika tidak menggunakan sisi creativity yang karyawan miliki akan membuat nasabah menjadi jenuh dan hal tersebut tidak akan membantu meningkatkan kinerja mereka pada perusahaan. Selain itu, karyawan akan mendapatkan bonus insentif ketika mereka bisa mencapai target perusahaan yang telah ditetapkan. Bonus insentif di sini menjadi pemicu karyawan untuk dapat meningkatkan kreatifitasnya dalam meningkatkan kinerjanya.

\section{Pengaruh Employee Engagement terhadap Job Performance melalui Creativity Karyawan Industri Perbankan di Kabupaten Sumenep}

Pengujian hipotesis menggambarkan bahwa creativity memediasi hubungan keterkaitan antara employee engagement terhadap job performance pada karyawan industri perbankan di Kabupaten Sumenep, sehingga $\mathrm{H} 4$ pada penelitian ini diterima. Ini telah membuktikan bahwa hubungan employee engagement pada karyawan industri perbankan di Kabupaten Sumenep memengaruhi job performance karyawan apabila dimediasi oleh creativity. Creativity di sini muncul ketika karyawan merasa engaged, nyaman, dan semangat pada pekerjaan mereka sehingga dapat meningkatkan job performance karyawan industri perbankan di Kabupaten Sumenep itu sendiri. Secara keseluruhan, penelitian ini memberikan bukti jelas bahwa hubungan antara employee engagement dan job performance terdapat faktor-faktor lain yang memediasi hubungan antara dua konstruk ini (Karatepe \& Ngeche, 2012). Penelitian ini juga memiliki hasil yang sejalan dengan pendapat Ismail et al. (2019) dengan sampel penelitian pekerja di berbagai bidang industri di Lebanon, di mana hasilnya creativity sepenuhnya memediasi hubungan antara employee engagement dan job performance. 
Agil Rasul Baharsyah \& Dwiarko Nugrohoseno. Pengaruh Employee Engagement terhadap Job Performance melalui Creativity sebagai Variabel Mediasi

\section{KESIMPULAN}

Berdasarkan hasil uji olah data penelitian terhadap hipotesis yang telah diajukan, ditemukan bahwa (1) employee engagement berpengaruh tidak signifikan terhadap job performance karyawan industri perbankan di Kabupaten Sumenep (2) Employee engagement berpengaruh signifikan terhadap creativity karyawan industri perbankan di Kabupaten Sumenep (3) Creativity berpengaruh signifikan terhadap job performance karyawan industri perbankan di Kabupaten Sumenep (4) Serta ditemukan pengaruh signifikan yang menjelaskan bahwa creativity memediasi hubungan antara employee engagement dan job performance karyawan industri perbankan di Kabupaten Sumenep.

Implikasi manajerial pada penelitian ini yaitu perusahaan perbankan di Kabupaten Sumenep disarankan dapat meningkatkan engagement para karyawannya saat ini serta memerhatikan kembali terkait faktor-faktor yang dapat menghambat atau menurunkan employee engagement mereka untuk menjaga kinerja perusahaan kedepannya. Salah satu faktor yang berdampak pada kinerja karyawan maupun perusahaan saat ini yaitu terjadinya pandemi covid-19 dan lingkungan internal perusahaan yang berubah. Sehingga, komunikasi antara perusahaan dengan karyawan harus tetap terjaga untuk meminimalisir terjadinya kesalahpahaman terkait pekerjaan mereka. Jumlah sampel pada penelitian ini merupakan keterbatasan yang dialami, sebab hanya dapat mengumpulkan sampel sebanyak 96 orang karyawan industri perbankan di Kabupaten Sumenep. Saran untuk pengembangan penelitian selanjutnya adalah peningkatan jumlah sampel penelitian yang akan digunakan, cakupan lingkup penelitian yang lebih luas, serta dapat memerluas hasil penelitian ini dengan menggunakan variabel konstruk selain variabel yang telah digunakan dalam penelitian ini seperti lingkungan kerja, kompensasi, dan turnover.

\section{DAFTAR PUSTAKA}

Ahmetoglu, G., Harding, X., Akhtar, R., \& Chamorro-Premuzic, T. (2015). Predictors of Creative Achievement: Assessing the Impact of Entrepreneurial Potential, Perfectionism, and Employee Engagement. Creativity Research Journal, 27(2), 198-205. https://doi.org/10.1080/10400419.2015.1030293

Alfes, K., Truss, C., Soane, E. C., Rees, C., \& Gatenby, M. (2013). The Relationship between Line Manager Behavior, Perceived HRM Practices, and Individual Performance: Examining the Mediating Role of Engagement. Human Resource Management, 52(6), 839-859. https://doi.org/10.1002/hrm.21512

Amabile, T. M., Conti, R., Coon, H., Lazenby, J., \& Herron, M. (1996). Assessing the Work Environment for Creativity. The Academy of Management Journal, 39(5), 1154-1184. https://doi.org/https://doi.org/10.2307/256995

Amabile, T. M., \& Kramer, S. J. (2007). Inner Work Life: Understanding the Subtext of Business Performance. Harvard Business Review, 85(5), 72-83.

Anderson, N., Potočnik, K., \& Zhou, J. (2014). Innovation and Creativity in Organizations: A Stateof-the-Science Review, Prospective Commentary, and Guiding Framework. Journal of Management, 40(5), 1297-1333. https://doi.org/10.1177/0149206314527128

Anitha, J. (2014). Determinants of Employee Engagement and Their Impact on Employee Performance. International Journal of Productivity and Performance Management, 63(3), 308323. https://doi.org/10.1108/IJPPM-01-2013-0008

Bakker, Arnold B., \& Bal, P. M. (2010). Weekly Work Engagement and Performance: A Study among Starting Teachers. Journal of Occupational and Organizational Psychology, 83(1), 189-206. https://doi.org/10.1348/096317909X402596 
Citradi, T. (2021). Persaingan Bank Digital di RI Makin Seru, Siapa Jadi Jawara? CNBC Indonesia. https://www.cnbcindonesia.com/market/20210203022555-17-220598/persaingan-bank-digitaldi-ri-makin-seru-siapa-jadi-jawara/3, diakses 17 Maret 2021.

Dajani, M. A. Z. (2015). The Impact of Employee Engagement on Job Performance and Organisational Commitment in the Egyptian Banking Sector. Jouranal of Business and Management Sciences, 3(5), 138-147. https://doi.org/10.12691/jbms-3-5-1

Deadrick, D. L., \& Gardner, D. G. (1999). Performance Distributions: Measuring Employee Performance Using Total Quality Management Principles. Journal of Quality Management, 4(2), 225-241. https://doi.org/10.1016/s1084-8568(99)00014-0

Demerouti, E., \& Cropanzano, R. (2010). From Thought to Action: Employee Work Engagement and Job Performance. In A. B. Bakker \& M. P. Leiter (Eds.), Work Engagement: A Handbook of Essential Theory and Research (pp. 147-163). Psychology Press, New York.

El-Sabaa, S. (2001). The Skills and Career Path of an Effective Project Manager. International Journal of Project Management, 19(1), 1-7. https://doi.org/10.1016/S0263-7863(99)00034-4

Eldor, L. (2017). Looking on the Bright Side: The Positive Role of Organisational Politics in the Relationship between Employee Engagement and Performance at Work. Applied Psychology, 66(2), 233-259. https://doi.org/10.1111/apps.12090

Eschleman, K. J., Madsen, J., Alarcon, G., \& Barelka, A. (2014). Benefiting from Creative Activity: The Positive Relationships between Creative Activity, Recovery Experiences, and Performance-Related Outcomes. Journal of Occupational and Organizational Psychology, 87(3), 579-598. https://doi.org/10.1111/joop.12064

Ghosh, K. (2015). Developing Organizational Creativity and Innovation: Toward a Model of Selfleadership, Employee Creativity, Creativity Climate and Workplace Innovative Orientation. Management Research Review, 38(11), 1126-1148. https://doi.org/https://doi.org/10.1108/MRR-01-2014-0017

Ghozali, I. (2014). Structural Equation Modeling: Metode Alternatif dengan Partial Least Square $(P L S)$ (Edisi 4). Semarang: Badan Penerbit Universitas Diponogoro.

Harter, J. K., Schmidt, F. L., \& Keyes, C. L. M. (2003). Well-being in the Workplace and Its Relationship to Business Outcomes: A Review of the Gallup Studies. Flourishing: Positive Psychology and the Life Well-Lived., January, 205-224. https://doi.org/10.1037/10594-009

Hughes, D. J., Lee, A., Tian, A. W., Newman, A., \& Legood, A. (2018). Leadership, Creativity, and Innovation: A Critical Review and Practical Recommendations. The Leadership Quarterly, 29(5), 549-569. https://doi.org/10.1016/j.leaqua.2018.03.001

INSEAD. (2020). The Global Talent Competitiveness Index 2020: Global Talent in the Age of Artificial Intelligence (B. Lanvin \& F. Monteiro (eds.)). The Adecco Group, Fontainebleau, France. https://www.insead.edu/sites/default/files/assets/dept/globalindices/docs/GTCI-2020report.pdf, diakses 20 April 2021

Isaksen, S. G., \& Ekvall, G. (2010). Managing for Innovation: The Two Faces of Tension in Creative Climates. Creativity and Innovation Management, 19(2), 73-88. https://doi.org/10.1111/j.14678691.2010.00558.x

Ismail, H. N., Iqbal, A., \& Nasr, L. (2019). Employee Engagement and Job Performance in Lebanon: The Mediating Role of Creativity. International Journal of Productivity and Performance 
Agil Rasul Baharsyah \& Dwiarko Nugrohoseno. Pengaruh Employee Engagement terhadap Job Performance melalui Creativity sebagai Variabel Mediasi

Management, 68(3), 506-523. https://doi.org/10.1108/IJPPM-02-2018-0052

Kahn, W. A. (1990). Psychological Conditions of Personal Engagement and Disengagement at Work. $\begin{array}{llll}\text { Academy of } \text { Management } & \text { 69urnal, }\end{array}$ https://doi.org/https://doi.org/10.5465/256287

Karatepe, O. M., \& Ngeche, R. N. (2012). Does Job Embeddedness Mediate the Effect of Work Engagement on Job Outcomes? A Study of Hotel Employees in Cameroon. Journal of Hospitality Marketing and Management, 21(4), 440-461. https://doi.org/10.1080/19368623.2012.626730

Kong, Y., \& Li, M. (2018). Proactive Personality and Innovative Behavior: The Mediating Roles of Job-Related Affect and Work Engagement. Social Behavior and Personality, 46(3), 431-446. https://doi.org/10.2224/sbp.6618

Macey, W. H., \& Schneider, B. (2008). The Meaning of Employee Engagement. Industrial and Organizational Psychology, 1(1), 3-30. https://doi.org/10.1111/j.1754-9434.2007.0002.x

Mahadika, C., \& Hadi, M. A. (2018). Pengaruh Keterlibatan Karyawan, Lingkungan Kerja dan Budaya Perusahaan terhadap Kinerja Karyawan pada PT. Jolin Permata Buana Kota Batam. Jurnal Equilibiria, 5(1), 51-63. https://doi.org/https://doi.org/10.33373/jeq.v6i2.2252

Markos, S., \& M. Sridevi, S. (2010). Employee Engagement: The Key to Improving Performance. International Journal of Business and Management, 5(12), 89-96.

Mathisen, G. E., Einarsen, S., \& Mykletun, R. (2012). Creative Leaders Promote Creative Organizations. International Journal of Manpower, 33(4), 367-382. https://doi.org/10.1108/01437721211243741

Munparidi, M., \& Sayuti, A. J. (2020). Pengaruh Keterlibatan Karyawan terhadap Kinerja Karyawan melalui Kepuasan Kerja sebagai Variabel Mediasi. Jurnal Aplikasi Manajemen Dan Bisnis, l(1), 2020. https://doi.org/https://doi.org/10.5281/zenodo.3952892

Murphy, K. R., \& Kroeker, L. P. (1989). Dimensions of job Performance. Navy Personnel Research and Development Center, 88(39), 1-32. https://apps.dtic.mil/sti/pdfs/ADA194951.pdf

Parker, S. K., \& Griffin, M. A. (2011). Understanding Active Psychological States: Embedding Engagement in a Wider Nomological Net and Closer Attention to Performance. European Journal of Work and Organizational Psychology, 20(1), 60-67. https://doi.org/10.1080/1359432X.2010.532869

Parlinda, V., \& Wahyuddin, M. (2008). Pengaruh Kepemimpinan, Motivasi, Pelatihan, dan Lingkungan Kerja terhadap Kinerja Karyawan pada Perusahaan Daerah Air Minum Kota Surakarta. Jurnal Pascasarjana Universitas Muhammadiyah Surakarta. http://eprints.dinus.ac.id/5077/1/11392.pdf

Perrin, T. (2003). Working Today: Understanding What Drives Employee Engagement the 2003 Towers Perrin Talent Report U.S. Report. https://studylib.net/doc/12886509/understandingwhat-drives-employee-engagement-working-tod..., diakses 2 Mei 2021

Sanny, L., Cahyani, R. A. B., \& Andhika, Y. (2013). Analisis Pengaruh Lingkungan Kerja dan Motivasi terhadap Kreativitas Karyawan Perum Pegadaian (Kanwil). Binus Business Review, 4(1), 389-397. https://doi.org/10.21512/bbr.v4i1.1170

Schaufeli, W. B., Bakker, A. B., \& Salanova, M. (2006). The Measurement of Work Engagement 
with a Short Questionnaire: A Cross-National Study. Educational and Psychological Measurement, 66(4), 701-716. https://doi.org/10.1177/0013164405282471

Shalley, C. E., \& Gilson, L. L. (2004). What Leaders Need to Know: A Review of Social and Contextual Factors That Can Foster or Hinder Creativity. The Leadership Quarterly, 15(1), 3353. https://doi.org/10.1016/j.leaqua.2003.12.004

Sharma, D., Borna, S., \& Stearns, J. M. (2009). An investigation of the Effects of Corporate Ethical Values on Employee Commitment and Performance: Examining the Moderating Role of Perceived Fairness. Journal of Business Ethics, 89(2), 251-260. https://doi.org/10.1007/s10551-008-9997-4

Shin, S. J., Kim, T.-Y., Lee, J.-Y., \& Bian, L. (2012). Cognitive Team Diversity and Individual Team Member Creativity: A Cross-Level Interaction. Academy of Management Journal, 55(1), 197212. https://doi.org/10.5465/amj.2010.0270

Singh, J., Verbeke, W., \& Rhoads, G. K. (1996). Do Organizational Practices Matter in Role Stress Processes? A Study of Direct and Moderating Effects for Marketing-Oriented Boundary Spanners. Journal of Marketing, 60(3), 69-86. https://doi.org/10.2307/1251842

Slatten, T., \& Mehmetoglu, M. (2011). Antecedents and Effects of Engaged Frontline Employees: A Study from the Hospitality Industry. Managing Service Quality, 21(1), 88-107. https://doi.org/10.1108/09604521111100261

Soori, Z., \& Ferasat, H. (2016). The Relationship between Creativity and Job Performance Khorramabad Municipal Departments. Journal of Applied Environmental and Biological Sciences, 6(3), 192-198. https://www.textroad.com/pdf/JAEBS/J. Appl. Environ. Biol. Sci., 6(3S)192-198, 2016.pdf

Stairs, M., \& Galpin, M. (2009). Positive Engagement: From Employee Engagement to Workplace Happiness. In N. Garcea, S. Harrington, \& P. A. Linley (Eds.), Oxford Handbook of Positive Psychology and Work. Oxford University Press. https://doi.org/10.1093/oxfordhb/9780195335446.013.0013

Suh, T., \& Shin, H. (2005). Creativity, Job Performance and Their Correlates: A Comparison between Nonprofit and Profit-Driven Organizations. International Journal of Nonprofit and Voluntary Sector Marketing, 10(4), 203-211. https://doi.org/10.1002/nvsm.31

Taboli, H., \& Mostafa, Z. (2016). Examine the Effect of Individual Creativity on Job Performance with the Mediating Role of Ethical Leadership of Headquarters Staff of Hormozgan University of Medical Sciences. Medwell Journals, 10(8), 1427-1433. https://doi.org/10.36478/ibm.2016.1427.1433

Thomas, C. H. (2007). A New Measurement Scale for Employee Engagement: Scale Development, Pilot Test, and Replication. Academy of Management, 2007(1), 1-6. https://doi.org/10.5465/ambpp.2007.26501848

Tong, Z., Zhu, L., Zhang, N., Livuza, L., \& Zhou, N. (2019). Employees' Perceptions of Corporate Social Responsibility and Creativity: Employee Engagement as a Mediator. Social Behavior and Personality, 47(12). https://doi.org/10.2224/SBP.8479

Truss, C., Shantz, A., Soane, E., Alfes, K., \& Delbridge, R. (2013). Employee Engagement, Organisational Performance and Individual Well-Being: Exploring the Evidence, Developing the Theory. The International Journal of Human Resource Management, 24(14), 2657-2669. https://doi.org/10.1080/09585192.2013.798921 
Agil Rasul Baharsyah \& Dwiarko Nugrohoseno. Pengaruh Employee Engagement terhadap Job Performance melalui Creativity sebagai Variabel Mediasi

Viswesvaran, C., \& Ones, D. S. (2000). Perspectives on Models of Job Performance. International Journal of Selection and Assessment, 8(4), 216-226. https://doi.org/10.1111/1468-2389.00151

Widhiarso, W. (2010). Membuat Kategori Skor Hasil Pengukuran dari Skala. Yogyakarta: Univesitas Gadjah Mada.

Zhou, J., \& George, J. M. (2001). When Job Dissatisfaction Leads to Creativity: Encouraging the Expression of Voice. Academy of Management Journal, 44(4), 682-696. https://doi.org/10.5465/3069410 